\title{
Need for Clean Coal Mining in India
}

\author{
Sribas Goswami \\ Assistant Professor in Sociology, Serampore College, West Bengal, India
}

cross $^{\text {ref }}$ http://dx.doi.org/10.5755/j01.erem.66.4.4870

(Received in July, 2013; accepted in December, 2013)

\begin{abstract}
Coal mining contributes largely towards economic development of the nation although it has a great impact on the human health. It also has an impact on a socio-cultural aspect of workers and people residing in and around coal mining areas. Thus a holistic approach to taking up with mining activities, keeping in mind the concerns over adjoining habitats and ecosystem, is the need of the hour. This requires identification of various sites where minerals exist, of various factors ranging from an appropriate angle of the slope of overburden dumps to safe disposal drains, of safe techniques to various silt control structures etc. In India, coal companies are now working towards "clean coal" strategies which aim to reduce environmental impacts. The reduced ash contents of the washed coal increase thermal efficiency of combustion which, in turn, makes a direct impact on reducing emissions of pollutants. However, the coal washing requires extra water and it can turn towards a pollution free society.

Key words: pollution, coal mine, global warming.
\end{abstract}

\section{Coal mining in India}

Pollutants produced in mining to burning of coal damage not only the earth surface to the atmosphere, the hydraulic regime to bio-diversity but also threaten the very survival of humankind by global warming. On the other hand, the energy generated from coal is essential for industrialization, employment generation and quality improvement of human life. The mining operation involves environmental disturbance with a negative impact upon ecology, bio-diversity and social fabrics. Coal (both surface and underground) contributes to nearly $35 \%$ of the total mineral wealth of India and causes the largest earth moving operation by volume. Clean coal initiatives are those which facilitate the exploitation and utilization of coal economically and in an eco-friendly manner, keeping emissions of greenhouse gases within the sustainable limit. A basic approach to the clean coal initiative is to mine coal with the minimum quality dilution, to prepare coal to segregate waste rock and to stow it back below the earth crust; to transport coal with a minimum vehicular exhaust, noise and to use it for industrial purposes with high fuel efficiency, minimum generation of waste and greenhouse gases. The inefficiency of mining and coal preparation are manifested during combustion not only in the form of inefficient power plants but also by heavy emissions of pollutants damaging even the ozone layers. Various technologies are undergoing development in order to improve the quality of coal during and after mining and to provide an environmentally satisfactory method of using coal as a basic fuel for power production. There is also a need for improving the technology for transport and beneficiation so that the pollution level may be controlled to make the earth worth living. Lack of effective legislation concerning subsidence in mines is lagging behind in India.

\section{Sources of data \& methodology}

The methodology of the study includes collection of research material over the field study and observation methods. The present study is based on both Primary and Secondary data. Primary data are collected from a structured interview schedule with the officers of Coal India Ltd. and secondary data are collected from CMPDI records, journals of IICM (Indian Institute of Coal Management) and books related to coal mines. The field study was conducted from the Coal India Headquarters in the year of 2012. 


\section{Coal mining technology in India}

India has emerged as a third largest coal producer of the world having nearly $6.4 \%$ of the share in the total world coal production, though its reserve is limited to only $1 \%$ of the world's reserve estimated as 205.9 billion tons. The electricity energy consumption rate of India has been nearly $7 \%$ during this decade, and coal alone has accounted for nearly $70 \%$ of the total commercial energy. The present energy (2012) production of India is only $2.3 \%$ of that in the world in comparison to $10 \%$ for China and $21 \%$ for the USA. The demand for electrical energy in India is growing at a rate of $9 \%$ per year which can be met by additional power generation by coal fired generators. The National Thermal Power Corporation (NTPC) has been playing a pivotal role in this direction with nearly 15245 MW (NTPC Mannual2012) of installed power generation capacity. To meet the rising demand, the country has opened up its boundaries to the global community including import of coal and development of captive mines. The coal quality affects every aspect of power plants including maintenance, performance and efficiency. Every step of mining, transportation and beneficiation of coal has serious impact on the environment, climatic change and ecology. The mining sequence, method of mining, ground control and control of dilution and mixing of waste rock affect the quality of coal.

Clean coal mining initiative has become essential in view of extensive damage to the environment with the surface mining and even with underground mining. The ash contents of the inferior coal in the surface mining are increasing with the size of the earth moving machinery when the bands are worked along with the coal. Mining of gassy coal seams and its combustion for power generation are the major sources of methane and carbon dioxide. According to the estimates of a recent report published by the Ministry of Power, Govt. of India in 2012, nearly 31300 million tons of carbon dioxide and 255 million tons of methane are produced in the world every year which are much beyond the cleansing limits of the ocean and vegetation. The share of carbon dioxide and methane generation in India was estimated as $6 \%$ and $14.4 \%$ respectively of the total world amount by different sources. Damage to the ozone layer and the danger of global warming due to these two gases were discussed in the Montreal Protocol in 1987. The UNDP and the World Bank deliberated on (i) global warming and climatic change, (ii) biodiversity loss, (iii) ozone layer depletion and (iv) water pollution prevention, this followed Earth Summit 1992 of Brazil which evolved the consensus on sustainable use of world resources (Rio Summit- 2012).

\section{Clean coal mining in India}

Depending on geology, the floor of seams could be seat earth, mudstone, shale, or sandstone, soft or hard in nature with or without clear marker horizon. The mining process in the underground mining required working in a clean coal section to keep clean of band, weak fragile roof or floor rock.

The following options are possible for improving utility of coal during mining as suggested by CMPDI (Coal mining and planning development of India) (CMPDI Report-2013):

- Maintain horizon in mechanized mining, shearing or continuous mining

- Keep automatic horizon control in case of remotely operated coaling machines

- Stabilize weak roof against caving in and mixing to the coal mass

- Mine in sections, maintaining the bank as roof or floor of different sections

- Control over soft floor cutting and mixing with coal

- Control over erratic floor blasting particularly in case of dipping particularly in case of dipping seams

- Maintain selective mining of clean coal section.

In the case of surface mining, drills and coal handling machines (loading and transport) being of a giant size are not sensitive enough to segregate thin bands, intrusions and waste material. Even bench formation and cleaning and removal of burden are not always practiced in most of the surface mines. The spillage of waste rock or burden and mixing with coal in many cases has resulted in dilution of coal.

Hence, it is clear from the above discussion that the clean coal mining concept reduces harmful effects of coal mining and improves the environmental status in a coal mining region.

\section{Coal mining activities and global warning}

Mining is ancient and one of the most useful industrial economical developments in India. About $75 \%$ of the World's mineral output comes from opencast mines. Opencast mines need land for pit and dumping ground. Thus, the ecosystem degradation is more from opencast than underground mines.

Coal mining has a special significance due to its high pollution nature. Being fossil fuel coal has been one of the most economical minerals. The coal reserves in India are indicated at 200 billion tons, and almost $73 \%$ of reserves are inferior grade non-coking coal. As such, dependence on the poor quality coal (35 to $48 \%$ ash), even with comparatively low sulphur content less than $0.6 \%$, poses significant environmental problems which need to be addressed through appropriate management and technological interventions throughout the coal- cycle. A relative share of coal as a fuel in electricity generation as well as in industrial and domestic sectors has been on an increase over the last two decades. Sector wise coal demand projections are given in the following Table 1 
Table 1. Sector wise coal demand projections in India

\begin{tabular}{|l|c|c|c|c|}
\hline \multirow{2}{*}{ Sector } & \multicolumn{4}{|c|}{ Coal demand projection (Mt) } \\
\cline { 2 - 5 } & $\mathbf{1 9 8 9 - 9 0}$ & $\mathbf{1 9 9 6 - 9 7}$ & $\mathbf{1 9 9 9 - 2 0 0 0}$ & $\mathbf{2 0 0 8 - 1 2}$ \\
\hline & 118 & 175 & 218 & 203 \\
Power (Utilities) & 13 & 16 & 26 & 32 \\
Power (Captive) & 6 & 3 & 2 & 60 \\
Transport & 33 & 44 & 50 & 102 \\
Industry (Iron \& steel) & 44 & 60 & 75 & 19 \\
Industry (Others) & 8 & 11 & 15 & $\mathbf{4 1 6}$ \\
Domestic \& Other & $\mathbf{2 2 2}$ & $\mathbf{3 0 9}$ & $\mathbf{3 8 6}$ & \\
\hline \multicolumn{1}{|c|}{ Total (mt) } & & & \\
\hline
\end{tabular}

Sources: CMPDI Survey Report, 201

Since the present coal production in the country is only about 229 million tons (See Coal India Annual report-2012), the coal demand and supply position clearly points that additional coal supply can be met through either expansion of existing operations or taking up of new coal mining projects to supply almost $187 \mathrm{Mt}(416 \mathrm{mt}-229 \mathrm{mt})$ of more coal by the year 2008-12.

The burning of coal produces huge amounts of fumes containing carbon dioxide $\left(\mathrm{CO}_{2}\right)$, carbon monoxide $(\mathrm{CO})$ and other gases like sulphur dioxide $\left(\mathrm{SO}_{2}\right)$, nitrous oxide $\left(\mathrm{NO}_{\mathrm{X}}\right)$, methane $\left(\mathrm{CH}_{4}\right)$, hydrogen sulphide $\left(\mathrm{H} 2_{\mathrm{S}}\right)$ etc. Fumes also contain solid suspended particulate matter (SPM). When gases are emitted to the troposphere, these allow Sun's rays penetrate the earth but, due to specific properties of the gas, do not permit all of the heat to reradiate back to the atmosphere, resulting in an increase in the temperature of the earth surface. This, in turn, may affect climate, agricultural responses, human and animal reactions, ocean levels and land use.

\subsection{Effect of coal pollutants on greenhouse}

The greenhouse effect may be broadly defined as an increase in the earth temperature due to heat trapping. Gases such as $\mathrm{CO}_{2}, \mathrm{CH}_{4}, \mathrm{NO}_{\mathrm{X}}, \mathrm{SO}_{2}$ water vapors, chlorofluorocarbons (CFCs) etc are the major "greenhouse" gases. Presence of these gases in small quantities helps to maintain the present mean temperature of $+15^{\circ} \mathrm{C}$. The earth mean temperature would be $-18^{0} \mathrm{C}$, if the "greenhouse effect" does not exist.

The pollutants from coal combustion are mainly $\mathrm{CO}_{2}$ and $\mathrm{NO}_{2}$ sand they become increasingly oxidized in the atmosphere. This causes an increase in acidity of rain water, dry deposition of SPM over trees at night due to the cooling of the atmosphere. In the day time these particles increase the temperature of tree leaves. The soft part of the leaf cannot sustain the increased temperature and, finally, it loses fertility and growth. This phenomenon is very common near the opencast mines and the power generation plants.

Chlorofluorocarbons (CFCs) are a major concern because of their double effect, i.e. their radioactivity and their influence on the stratospheric ozone layer. Combustion of fossil fuels and other human activities produce CFCs.

\subsection{Global warming}

Changes in the climate likely to be brought about by a global greenhouse effect are the threat to the future welfare of humanity. Widespread fear of these effects and depletion of atmospheric ozone has created a new wave in international scientific, technological and geopolitical discussions.

Table 2. Annual increase rate of greenhouse gases in India

\begin{tabular}{||l|c||}
\hline \multicolumn{1}{||c||}{ Radioactive gases } & Approx. Average Annual increase (\%) \\
\hline Carbon dioxide & 0.4 \\
\hline Methane & 1.3 \\
\hline Nitrous oxide & 0.3 \\
\hline Frepm -11 & 5.0 \\
\hline Methyl & 10.0 \\
\hline
\end{tabular}

Sources: CMPDI Survey Report, 2012

At present the contribution of carbon dioxide to global warming is roughly $50 \%$. The other $50 \%$ is due to the other gases such as methane, nitrous oxide and chlorofluorocarbons. These latter gases are 1,000 to 10,000 times more effective than carbon dioxide. At current rates of emissions, committed global warming will increase by $0.2{ }^{0} \mathrm{C}$ to $0.5^{0} \mathrm{C}$ every 10 years. This temperature rise would cause the water in the oceans to expand and the massive polar glaciers to melt.
Greenhouse effect is caused by an excess of $\mathrm{CO}_{2}$ in the atmosphere which is the result of extensive burning of fossil fuels, and deforestation which has accelerated during the past decade. It is estimated that 225 billion tons of carbon is removed annually from the atmosphere by forests and oceans. However, 228 billion tons of carbon is added (see CMPDI Report2012,p-14), 5.5 billion tons of which are from the 
burning of fossil fuels and 2.2 billion tons are released by deforestation.

Deforestation can cause global warming. Sometimes, due to the effect of the wind, hazardous gases and SPM travel larger distances in the direction of the wind and disturb the ecosystem far away from their original place, e.g. the ozone hole of Antarctica is produced due to environmental degradation of some developed countries. A rise in the sea levels, inevitable if current trends continue, would threaten coastal regions within few decades with submergence of the islands of Maldives, parts of Bangladesh, India and even the area such as the state of Louisiana in the USA.

\section{A role of coal mining in degrading the environment}

Coal mining is a major industry in development of India. Since opencast mining is popular, the major production of coal comes from opencast mines. Waste dump of coal mines contaminates the air by emitting smoke and foul gas due to spontaneous combustion. Blasting and diesel equipment is the source generating harmful gases like $\mathrm{CO}_{2}, \mathrm{NO}_{\mathrm{X}}, \mathrm{CO}, \mathrm{CH}_{4}, \mathrm{H}_{2} \mathrm{O}, \mathrm{SO}_{2}$ etc which are serious for "greenhouse effect". According to the CMPDI report, 158 incidents of mine fires occurred in India and there were 70 active fires in 40 collieries covering the area of 17.32 sq. $\mathrm{km}$ (see CMPDI Report-2012, p-32). These fires have sterilized 1491 million tons of coal in opencast blocks and 373 million tons in underground blocks. Apart non-coking coal, the fires have also blocked huge amounts of coal reserves of the order of 1894 million tons in underlying/overlaying seams. The report has also estimated the methane emission from coal mining on the basis of classifying the coal seams into three groups, namely, Degree-I, Degree-II and Degree III, depending upon their gassiness. The total emission of methane is estimated to have been 0.346 Mt during the year 2000-2012 in India (see CMPDI Report2012, p-35).

Release of gaseous emission from these fires contributes to the concentration of green house gases in the atmosphere. The quantum of gases released in the atmosphere can be appreciated from the fact that the first fire that broke out in 1916 is still burning with many more fires added subsequently. The need for controlling the mine fires is thus self-evident, and an extensive program is in hand for their control, so that the damage to life and property as well as short and long term micro and macro climatic changes can be averted and controlled.

Disposal of waste, open pit mining and other accessory activities cause deforestation of the areas. Spreading of toxic waste destroys the vegetation. Coal reserves cover an area of 2.13 million hectares in India and there already exist 119 abandoned coal mines. Land degradation due to opencast coal mining operations is reported to be at the rate of 4 ha per million tons of coal production. At this rate, coal mining operations alone would continue to render the unproductive area of more than 1400 ha every year by the year 2012 (see CMPDI Report-2012). Massive deforestation drastically changes the climatic condition like rainfall, temperature and humidity. Deforestation also causes the loss of oxygen fixing capacity, wood, soil nutrient and water table. Pollution of drinking water, air, reduction of fertility of agricultural lands, crop yield capacity etc affects the society in general.

\section{Measures to protect the environment in mining areas}

Protection and preservation of our global environment have been a growing concern all over the world. There is a need to initiate immediate actions in the following areas, so that projected changes in the climate do not add much in social, economic and ecological problems:

- Solar energy generation is confined to day-time and further limited by cloudy days; some scientists suggest transferring the bulk of power production to solar-power-generation satellites. Heat mining is a source of energy. Geothermal energy can be extracted from the earth's crust by safe, economically and environmentally acceptable methods.

- Production of biogas and wind energy can also serve as alternative sources of energy. The country needs a policy of both improving the efficiency of energy use at all levels and promoting the widespread developments. The present policy of the Indian Government regarding biogas production is framed but its execution part is to be completed.

- There should be an intensification of efforts to protect the remaining forests in the country and to promote the forestation of degraded forests and waste lands. Exploitation of the potential plant science to enrich the surface greenery and green canopy of the forests is of great importance. This is essential for absorbing more carbon dioxide from the atmosphere, and also for the conservation of the biological diversity for current and future needs.

- Dust lift-off from the waste dump can be controlled by establishing vegetation on the dump surface, keeping the surface moist by using sprinkler irrigation and water sprays on haul roads. Dust emissions from blasting are to be limited and in major dust centres like coal handling plants, adequate measures for dust controlling by dust suppression, dust extraction, vegetative barriers separating mining activities from adjoining areas should be taken.

- Smoke and gases from burning stock piles can be controlled by water quenching over the surface of dumps, blanketing the surface with a layer of incombustible material like limestone, clay, fine sand, dirt etc. 
- To tackle the air pollution arising out of the traditional soft coke production, there should be time limit to switch over to mechanize soft coke making. The control of pollution due to emissions or exhaust gases from trucks in large opencast mines should be paid due attention to.

- Waste dump and mined out areas should be properly reclaimed. The full range of agricultural techniques should be available to be applied as rapidly as possible to bring land back into the best agricultural production. Mixed planting or herbaceous vegetation and trees of the native plant species should be practiced to enhance wildlife utilization of reclaimed areas. The recent development in biotechnical engineering and advanced engineering has much improved the success rate in tree planting using some inoculants.

\section{Conclusions}

Climate change is now given the highest priority in the list of global environmental problems. The gases and pollutants emitted by coal extraction and combustion are factors that interconnect energy security, air pollution and greenhouse effect. In order to understand the implications of the global greenhouse effect, we need reliable information on the rate of emissions of carbon dioxide and certain other trace gases as a result of coal extraction and burning. Energy security will figure as the main global issue if there are to be concentrated efforts to reduce the carbon dioxide emissions. Solar-power satellites are a serious option in the future. Heat mining, wind energy and biogas can also become alternative sources of energy instead of coal. The initiative should be taken by all people to protect our global environment from pollution. There is no specific legislation in India concerning subsidence, but as per common law, the coal company is to acquire the surface right of the property in which subsidence may occur due to the underground mining. In some countries there is specific legislation guarding the coal industry in the case of subsidence, and perhaps such enactment may be the necessity of the day in our country also. In the foregoing discussions an attempt has been made to clarify the coal mining activities and its residual impact on the environment and human health. It is also clear that mining is a site specific activity and is carried out in the sites where this mineral exists. On the other hand, mining is considered an environmentally unfriendly activity.

\section{References}

Anthony, J. Davy, Martin R. Perrow: (2002), "Hand book of Ecological Restoration": Vol-2.

Areeparampil, S.J.M. (2008), "Displacement due to mining in Jharkhand", First World Mining Environment Congress, Dec. New Delhi, pp.527-548.

Biswas, A.K and Qu. Geping. (2007), "Environmental Impact Assessment for Developing Countries": Tycolly International, Londan , pp.232

Boliga.B.P. (1989), Mining (2010), “Challenges of environmental management", 4th National Convention of Mining Engineers, March, Dhanbad, India.

CMPDI Survey Report, 2012.p-12

Coal India Annual report-2012 p-120

Ghose, K.Mrinal. (2008). "Environment and pollution Awareness due to Mining Activities": Centre of Mining Environment, I.S.M, Dhanbad

NTPC Mannual-2012,p-334-335

Rao, D.N. (2011) "Air pollution and plant life" Department of Environment London

Singh, G. (2005). 'Water sustainability through augmentation of underground pumped out water for portable purpose from coalmines of Eastern India': Indian School of Mines, Dhanbad, India.

Saxena N.C., G. Singh and R. Ghosh (2010): 'Environment Management in mining areas', Centre of mining environment, I.S.M., Dhanbad.

Dr. Sribas Goswami - Assistant Professor in Sociology, Serampore College, West Bengal, India. Main research areas: Sociology of Environment,

Sociology of Development.

Address: Plot No. 20, 3rd Avenue, 2nd Street, Ulhas Township, Burdwan, West Bengal, India,PIN-713101

Phone: +913326529489

E-mail: sribasgoswami@gmail.com 


\title{
Švarios anglies kasybos poreikis Indijoje
}

\author{
S. Goswami \\ Serampore kolegija, Vakaru Bengalija, Indija
}

(gauta 2013 m. liepos mèn.; atiduota spaudai 2013 m. gruodžio mèn.)

Anglies kasyba daugiausia prisideda prie ekonominio valstybės vystymosi, o svarbiausia, didelę ittaką turi žmogaus sveikatai. Anglies kasyba taip pat daro poveiki sociokultūrinėje žmoniu aplinkoje - darbininkų ir gyvenančių netoli kasyklų aplinkoje. Taigi holistiniu požiūriu imantis kasybos veiklos ir darbu, vertetuc susirūpinti gretimomis gamtinemis buveinėmis ir ekosistemomis jau čia ir dabar. Dèl šios priežasties svarbu visapusiškai ịvertinti gretimą aplinką, kurioje gausu mineralų, taip pat įvarius veiksnius, pvz., parinkti tinkamą sąvartynų šlaitų kampą, įrengti patikimas drenažines sistemas ar parinkti tinkamą metodą nuosèdų sudèčiai kontroliuoti ir $\mathrm{t}$. $\mathrm{t}$. Indijoje anglies kompanijos šiuo metu dirba „ک̌varios anglies“ principu, kurios pagrindinis siekis yra sumažinti poveiki aplinkai. Sumažinus pelenų kieki grynintoje anglyje, padidèja terminis degimo efektyvumas, dèl ko sumažèja teršalų emisijos. Vis delto anglies gryninimui yra reikalingas papildomas vanduo, o tai gali sukelti taršą laisvoje visuomenèje. 